\title{
Modeling Policy Mix to Improve the Competitiveness of Indonesian Palm Oil Industry
}

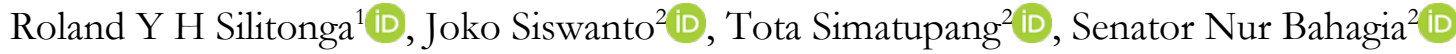 \\ ${ }^{1}$ Harapan Bangsa Institute of Technology (Indonesia) \\ ${ }^{2}$ Bandung Institute of Technology (Indonesia) \\ roland@ithb.ac.id,j.siswanto@mail.ti.itb.ac.id,.tsimatupang@mail.ti.itb.ac.id, senator@mail.ti.itb.ac.id
}

\section{Abstract:}

Purpose: The purpose of this research is to develop a model that will explain the impact of government policies to the competitiveness of palm oil industry. The model involves two commodities in this industry, namely crude palm oil (CPO) and refined palm oil (RPO), each has different added value.

Design/methodology/approach: The model built will define the behavior of government in controlling palm oil industry, and their interactions with macro-environment, in order to improve the competitiveness of the industry. Therefore the first step was to map the main activities in this industry using value chain analysis. After that a conceptual model was built, where the output of the model is competitiveness of the industry based on market share. The third step was model formulation. The model is then utilized to simulate the policy mix given by government in improving the competitiveness of Palm Oil Industry.

Findings: The model can accommodate government's policy mix which is then optimized. The model has been built structurally based on hierarchical multi-level system approach, while in the process element, the subprocesses are built using VCA approach. The model can simulate industry performance, and show that such government policy mix can improve the competitiveness of Indonesian palm Oil Industry.

Research limitations/implications: The model was developed using only some policies which give direct impact to the competitiveness of the industry. For macro environment input, only price is considered in this model. 
Practical implications: The model can simulate the output of the industry for various government policies mix given to the industry. The techno-economic aspect is also discussed.

Originality/value: This research develops a model that can represent the structure and relationship between industry, government and macro environment, using value chain analysis and hierarchical multilevel system approach.

Keywords: palm oil industry, competitiveness, hierarchical multilevel system, policy mix

\section{Introduction}

Globalization has caused an interdependency among nations which is characterized by openness of domestic market to products from other countries. The transformation of global economy leads to a strong competition among industry sectors in every country, to gain global market share. As a consequence, an industry has to have a high level of competitiveness. In order to increase the competitiveness, we have to solve the obstacles in the industry chains, government regulation and policy, and also international economic environment. In achieving this, the role of government to support the industry is very important. A study by Lall (2004) showed that government should take part in dealing with the globalization and technology changes. The causality between elements of public policy, private management strategy and industry competitiveness is critical (Martin, Westgren \& van Duren, 1991). Lall (2004) has shown that government intervention was needed to support the increase in competitiveness.

Palm oil industry has became Indonesia's economical main sector. Indonesia has become the largest producer of Palm Oil since 2007, and since 2009 has also become the largest exporter (Figure 1). The palm oil industry has a lengthy processes and many final products, but in Indonesia, the export markets are dominated by the raw products, namely Crude Palm Oil (CPO). This way, Indonesian export relies heavily on a low added value commodities. If the proportion of final products can be raised, income from export will eventually increase, and at the same time will improve the competitiveness of the industry as well. In this industry, environmental issues also exist, where the products should be from environtmentally and socially sustainable plantation. In response of this the Roundtable on Sustainable Pelm Oil was formed. RSPO developed global standards and requirements to ensure that the palm oil product is environtmentally and socially sustainable. The prove that the product meet the requirement is that the product earn certified sustainable palm oil (CSPO) label.

Because the industry is very important, government want to ensure that the industry is well developed. The government of Indonesia has issued several policies regarding palm oil industry. To protect and improve the production of small holder palm oil, there was subsidy policy. The Government also has issued policy to support sustainable palm oil. The policy is Indonesian Sustainable Palm Oil (ISPO), which is an Indonesia version of RSPO. These policies 
will ensure supportive environment to increase production and export, while also ensure that exported products suit the environmental aspects.

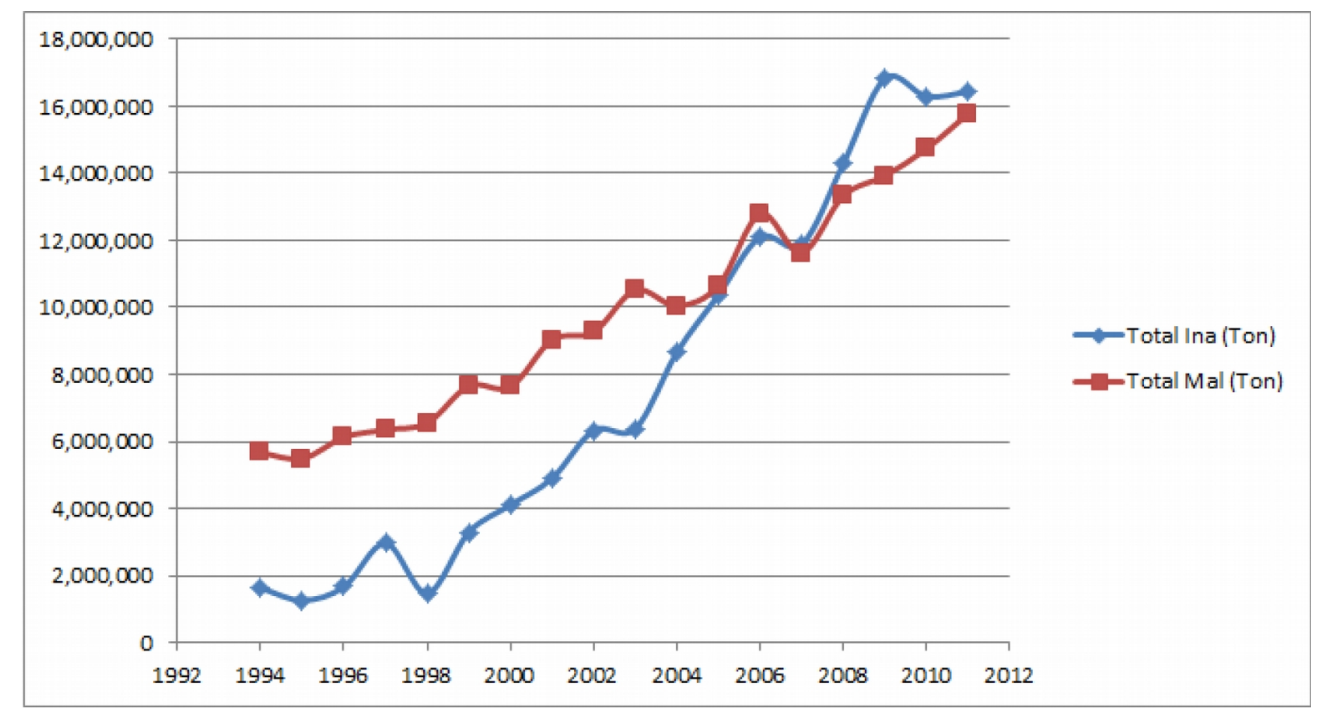

Data Source: UN Comtrade Database

Figure 1. Palm Oil Export: Indonesia and Malaysia (UN Comtrade Database, 2014)

The purpose of this paper is to develop a model that can describe and accommodate government as the coordinator of the industry. Government is perceived as the coordinator of the industry by giving policies, in order to improve competitiveness in macro (economic) environment. The model is expected to explain the impact of government policies by simulating the performance of industry which is measured by its competitiveness. This research also intends to build a model that can find optimal policy mix by government and its impact on industries, especially on international level of competition.

\section{Previous Studies}

There were many studies about the competitiveness of Indonesian palm oil industry such as by Marks, Larson, and Pomeroy (1998), Tambunan (2006), Rifin (2009), Susila (2004), Chalil (2008), Akyuwen and Sulistiyanto (2010) also Rifin (2010). These studies can be categorized into two. The first, studies focusing on environment of both government's influence and international economic condition. The second, studies concentrating on production cost and income distribution received by stakeholders in the industry value chain. Both types of studies are still in partial state. These studies did not discuss the system, meso environment (government policies and regulations) and macro environment (international economic condition) simultaneously. Therefore these studies have not been able to present the factors affecting competitiveness in an integrative way.

Kaplinsky and Morris (2001) stated that competitiveness should be observed systemically. The complete, existing value chain should be analysed under the theme of increasing competitiveness and added value. This is also in accordance with Porter's statement (1990) that 
to obtain competitive advantage, value chain should be arranged as a system instead of separated elements. Thus, it is necessary to utilize value chain approach in defining the system, taking into account the chains relation within this industry, as well as the influence of macro and meso environment simultaneously. This idea aligns with the research of Martin et al. (1991) which revealed that competitiveness is highly dependent to controllable factors by the government and companies, and uncontrollable factors by international economic condition.

Based on that, there is a need to improve the competitiveness of Indonesian palm oil industry, by considering not only the value chain, but also government policies and international economic condition. Silitonga, Nur-Bahagia, Simatupang and Siswanto (2013) have developed a conceptual model of Indonesian palm oil industry competitiveness. Activities that give added values are identified, and they used hierarchical multi-level system approach (Mesarovic, Macko \& Takahara, 1970) to integrate government role in coordinating these activities to improve competitiveness. In this model the approach is used to formulate and simulate the policy mix applied to the industry.

\section{Modeling Indonesian Palm Oil Industries}

\subsection{Palm Oil Industry Value Chain}

Kaplinsky and Morris (2001) proposed value chain analysis (VCA) to understand an industry in improving its competitiveness. They developed VCA which is a method to analyse competitiveness of industry based on value adding activities within the industry. The value chain describes all activities (in industry) as a value added links, which is required in bringing a product or a service to market.

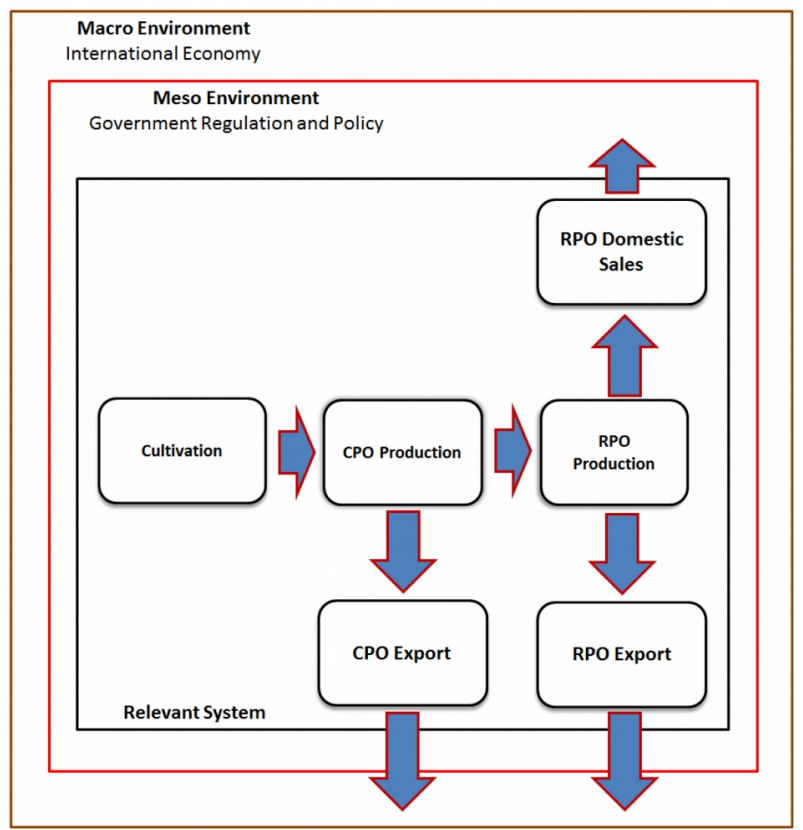

Figure 2. Indonesian Palm Oil Industry Value Chains 
Figure 2 shows the value chain process of Indonesian palm oil industry, focusing on crude palm oil (CPO) and refined palm oil (RPO). There are three main producers of fresh fruit bunch to be processed into $\mathrm{CPO}$ : smallholders (SH), state-owned companies (SC) and private companies (PC). Table 1 shows land proportion and production of the three main producers. Area of SH and PC are nearly the same, but SH has lower productivity. It can be seen that SH had around $45 \%$ proportion of the land, but the production in $2008-2010$ was less than $40 \%$. With this proportion, the smallholder has a significant role in improving national productivity. This low productivity is because $\mathrm{SH}$ did not implement proper management and technology. Here the government can give technology support policy such as subsidy to buy fertilizer, high quality seeds, or a replanting program.

\begin{tabular}{|c|c|c|c|c|c|c|c|c|c|}
\hline & \multicolumn{3}{|c|}{ SH } & \multicolumn{3}{|c|}{ PC } & \multicolumn{3}{|c|}{ SC } \\
\hline & 2008 & 2009 & 2010 & 2008 & 2009 & 2010 & 2008 & 2009 & 2010 \\
\hline $\begin{array}{l}\text { Production } \\
\text { (Ton) }\end{array}$ & $6,923,042$ & $7,247,979$ & $7,774,036$ & $9,442,557$ & $9,431,089$ & $9,980,957$ & $2,181,265$ & $1,961,813$ & $2,089,908$ \\
\hline $\begin{array}{l}\text { Production } \\
(\%)\end{array}$ & 37.33 & 38.88 & 39.17 & 50.59 & 50.59 & 50.29 & 11.76 & 10.52 & 10.53 \\
\hline Area (Ha) & $3,287,118$ & $3,536,060$ & $3,784,879$ & $3,277,321$ & $3,387,717$ & $3,498,113$ & 756,685 & 776,601 & 796,506 \\
\hline Area $(\%)$ & 44.90 & 45.92 & 46.85 & 44.77 & 43.99 & 43.30 & 10.33 & 10.08 & 9.85 \\
\hline $\begin{array}{l}\text { Productivity } \\
\text { (Ton/Ha) }\end{array}$ & 2.11 & 2.05 & 2.05 & 2.88 & 2.78 & 2.85 & 2,88 & 2.53 & 2.62 \\
\hline
\end{tabular}

Table 1. Productivity of producers in Indonesian palm oil value chain (Badan Pusat Statistik, 2012)

Crude palm oil (CPO) is either to be exported or sold domestically to undergo further process of refined palm oil (RPO), to become cooking oil and other derivatives. The balance between export and domestic, CPO or RPO, is controlled by market demand, which is represented by the price. If world demand increases the export price will increase, the proportion of export will increase, and vice versa. Cooking oil is a crucial domestic necessity, thus the existence of export taxed for this commodity (Rifin, 2010) is needed to control it. A study conducted by Susila (2004) shows that $1 \%$ increase in effective export tax contributes to $0.14 \%$ reduction of Indonesian CPO export, or about 14,000 ton/year.

In the recent years Indonesia's production has exceeded the domestic need of cooking oil. Domestic palm oil usage percentage has dropped through the last decade, from $27 \%$ in 2005 to 24\% in 2009 (Badan Pusat Statistik, 2012). However the domestic sale of CPO is still needed in bigger proportion to be further processed into RPO. This downstream product has higher values, due to its higher price. This will also improve the competitiveness of palm oil industry. Therefore, attention is necessary for RPO proportion in the whole export commodity of palm oil.

In the value chain there is also the role of government as regulator, represented by the relevant ministry for each phase. For cultivation and CPO processing, policies are issued by the Ministry of Agriculture. In the production of RPO (and other derivatives), policies are issued by 
the Ministry of Industry. In trading, both domestically and for exporting, policies are issued by the Ministry of Trade and the Ministry of Finance. The various policies issued can be either advantageous for one particular stakeholder but on the other hand disadvantaging the other, which will affect the competitiveness of the palm oil industry as a whole.

On the macro-environment level, there are 4 main factors that will influence the national palm oil industries, they are demand, substitute product, currency rate, and environmental issues (Susila, 2004; Akyuwen \& Sulistyanto, 2010; Rifin, 2009, 2010). High demand will cause a rise in export price. High demand also affected by rarity of substitute product for CPO, namely soybean oil and sunflower oil. High currency rate will raise the price of CPO and RPO, and vice versa. Social and environmental issues in the form of sustainable palm oil also become an important factor in considering the macro-environment. There is a need to ensure that the resulting CPO is derived from socially- and environmentally-conscious process. Since the 2000s these issues have become global and in 2007 Roundtable on Sustainable Palm Oil (RSPO) certification was initiated. Main goal of RSPO is to promote enhancement and usage of sustainable palm oil through cooperation in supply chain and open dialogues between stakeholders. RSPO certification will change the name of certified product to Certified Sustainable Palm Oil (CSPO). CSPO-labelled product will have a higher market price than non-CSPO product. Some of Indonesian stakeholders have already supported RSPO by establishing its own version called Indonesia Sustainable Palm Oil (ISPO).

Other aspects to be noted in this value chain is the role of the competitor. Palm oil markets around the globe are dominated by Indonesia and Malaysia. Combined, both makes up about $90 \%$ of palm oils sold around the world. Since 2007 , Indonesia has already surpassed Malaysia as the largest palm oil producer in the world. Nonetheless, in terms of revenue from exports, Indonesia doesn't seem to be able to achieve higher value than Malaysia. Therefore, in characterizing Indonesian palm oil industry competitiveness, dynamic comparison between Indonesia and Malaysia's market share is necessary. Figure 3 and 4 show the difference in proportion of exports between the two countries.

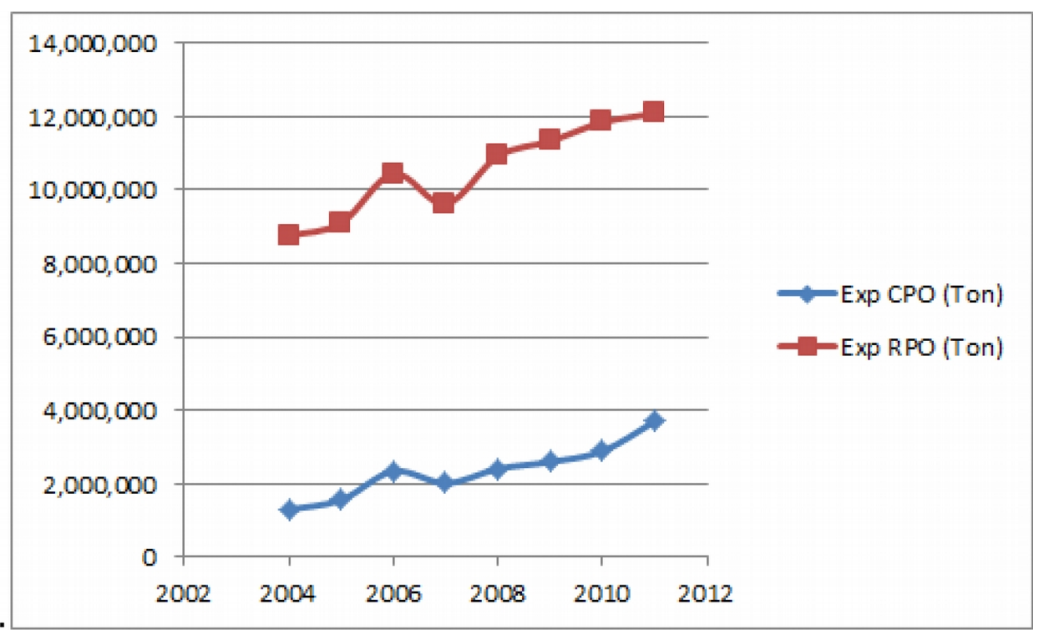

Figure 3. Malaysian CPO and RPO exports during 2004-2011 


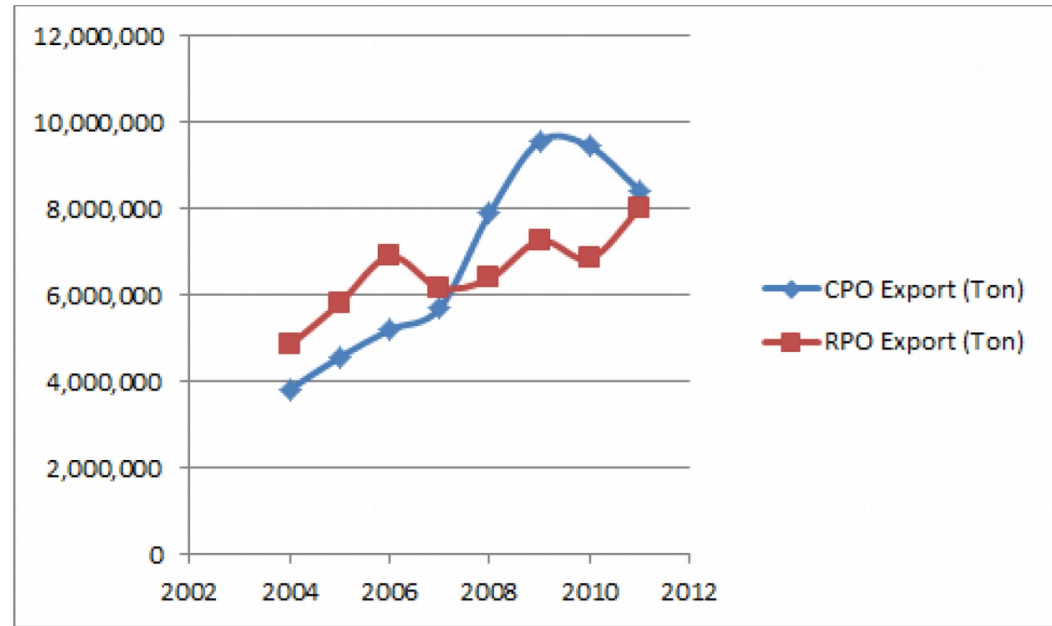

Figure 4. Indonesian CPO and RPO exports during 2004-2011

The development of the value chain into a conceptual model (Figure 5) is done by forming a system where government is not a part of the environment, but a part of the system, using hierarchical multi-level system approach (Mesarovic et al., 1970). In this respect, government becomes the coordinator of various activities in the industry, the highest level in this hierarchical model. Government is trying to coordinate the industry by the use of policy and regulation as coordination inputs to increase competitiveness. The increase of competitiveness is because of the productivity improvement and the change in proportion of domestic and export.

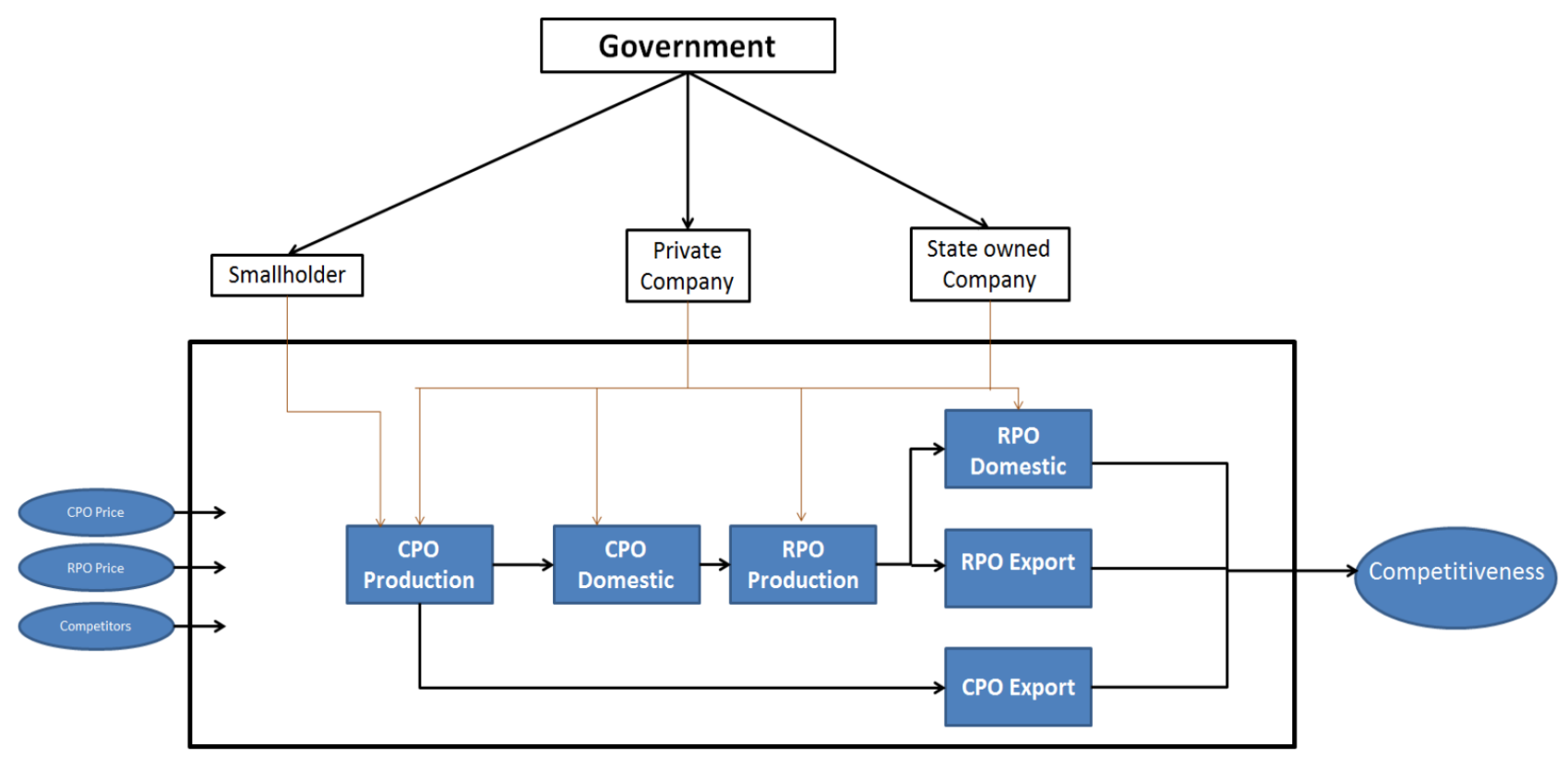

Figure 5. Conceptual Model of Palm Oil Industry Competitiveness 
At the next level there is Process where all big activities in the value chain to produce and sell CPO and RPO are arranged. The owners of the processes, which are SH, PC, SC. SH control the CPO production subprocess only, while PC and SC control all the subprocesses including export. The performance of these stakeholders is influenced by the policies that been given by the government. For example, as previously explained, technology factor supported by government in the form of subsidy can improve the productivity of $\mathrm{SH}$. There are also input from environment, the prices of CPO and RPO, and also the performance of competitor. The output of the model is competitiveness.

\subsection{Competitiveness Indicator}

Performance criteria of a model is very important. In this model the performance criteria is represented by high competitiveness. In order to understand the performance of the model, it is necesarry to know about the international competitiveness indicator of an industry. International competitiveness means being profitable while maintaining international market share, i.e. without protection (Martin et al., 1991; Siggel \& Ssemogerere, 2004). According to Siggel (2006), different types of competitiveness indicator can be categorized based on whether what being measured is actual performance (ex post) or latent potential that cannot be directly observed (ex ante). Porter (1990) stated that competitiveness is an ability to create products or services which can give more added value than competitors' products. This fact will be reflected in the sales and profit improvement. Martin et al. (1991) defined competitiveness as a sustained ability to profitably gain and maintain market share. By looking at these definitions, it can be concluded that competitiveness is a sustained ability to maintain or even increase the market share and added value. There are two indicators here to be considered, market share and added value. It should be noted that market share is an ex post indicator, while added value is an ex ante indicator. In this research the sum of market shares in value is chosen as competitiveness indicator. Market share in volume is ex post indicator so we can easily see the result of the policy. Price is assumed as the representation of value added. It is an ex ante indicator, so the potential is reflected there.

\subsection{Policy Mix}

In the model developed, policies to be included in the model are fiscal policies. Government tries to improve national palm oil industries by giving limiting or stimulating policies. Figure 6 shows fiscal policy mix that can be done by government in an effort to support national industries. As shown on Figure 6, it is possible for government to confine or motivate an activity, in the form of incentive or disincentive. Policies can also be protective, like import duty tariffs and Anti-Dumping Import Duty. In Indonesian palm oil industries, several policies currently applied are export tax, subsidies, and incentives. Policies to motivate the increase in 
production are subsidies, incentives, and liberation of import taxes, while confining incentives are export taxes.

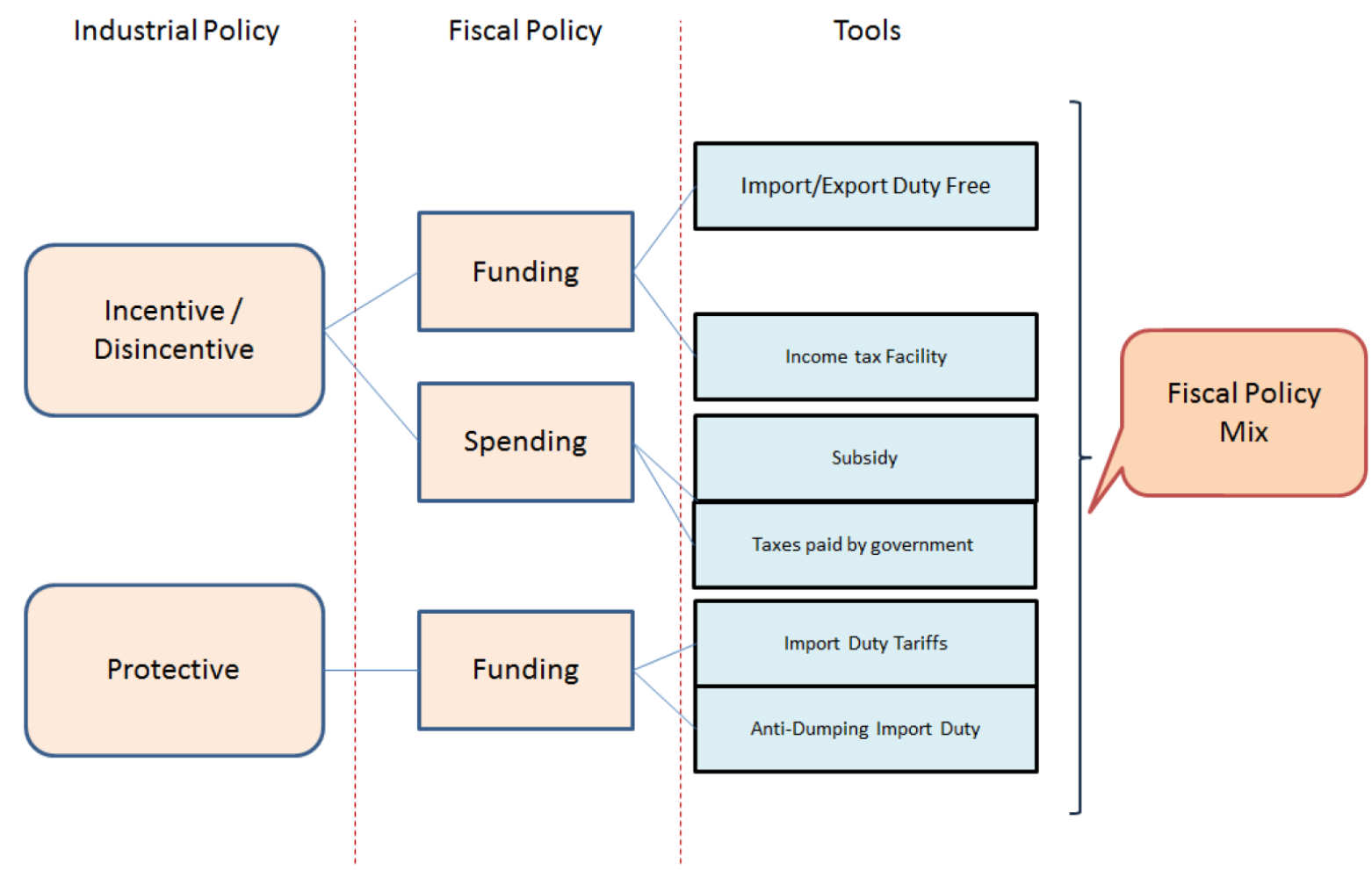

Figure 6. Indonesian Government Fiscal Policy Tools to support industries

\subsubsection{Export Tax Policies}

Indonesian government has had established various forms of policies related to palm oil industries. Before 1978, palm oil is an export-oriented commodity, with exported quantities made up for two-thirds of total production quantities. Since 1978, government allocated a quota for palm oil to satisfy domestic needs (Hasan, Reed \& Marchant, 2001). This policy was applied because of palm oil scarcity in the domestic market, which is the main ingredient for cooking oil. In June 1991, this policy was abolished by government in an effort to increase export and investment in this sector. This caused an increase in palm oil exports, as well as a rise in domestic price. In connection with the price increase, government applied export tax since 1994. Since then, export taxes are applied in various formulation of rates. Export tax tariffs are usually determined by Ministry of Finance, while check price (standard price for tax calculation based on international price of CPO) is determined by Ministry of Trade (Rifin, 2010). Government establishes export taxes to ensure the availability of CPO for cooking oil at a reasonable and affordable price (Susila, 2004). In other words, this policy is used to ensure domestic supplies of CPO. Moreover, it is also meant to develop domestic palm oil downstream industries, which will increase its added values, both for domestic needs and for export. However as proven from 1995-2009 condition, export tax is a short run policy, to 
stabilize the domestic cooking oil price (Rifin, 2010). It is not an effort of downstreaming the industries. Export tax is effective in confining export rates, but not in stabilizing domestic price (Chalil, 2008). It should be noted that increasing export tax could only be justified for developing downstream industries that used CPO as their main input. A complete depiction of government policy on export taxes towards CPO and RPO from 1990-2013 is presented in Figure 7 below.

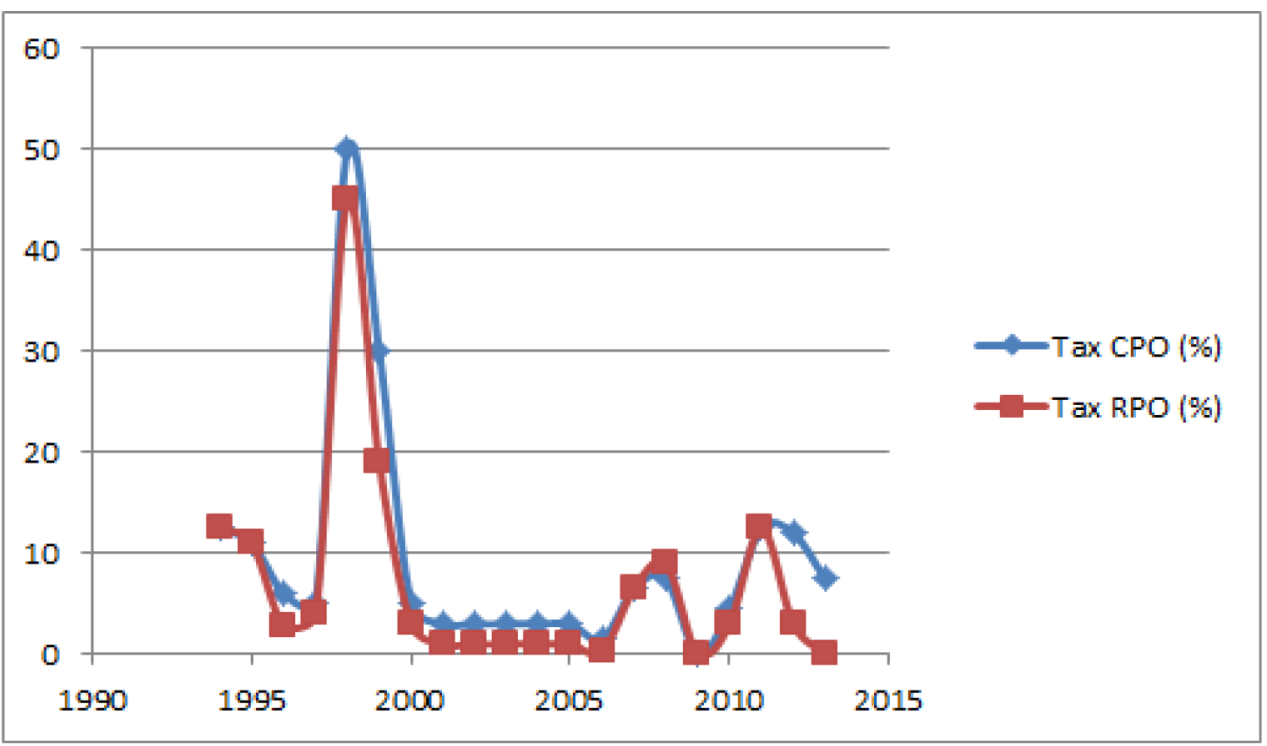

Figure 7. Effective Export Tax of CPO and RPO

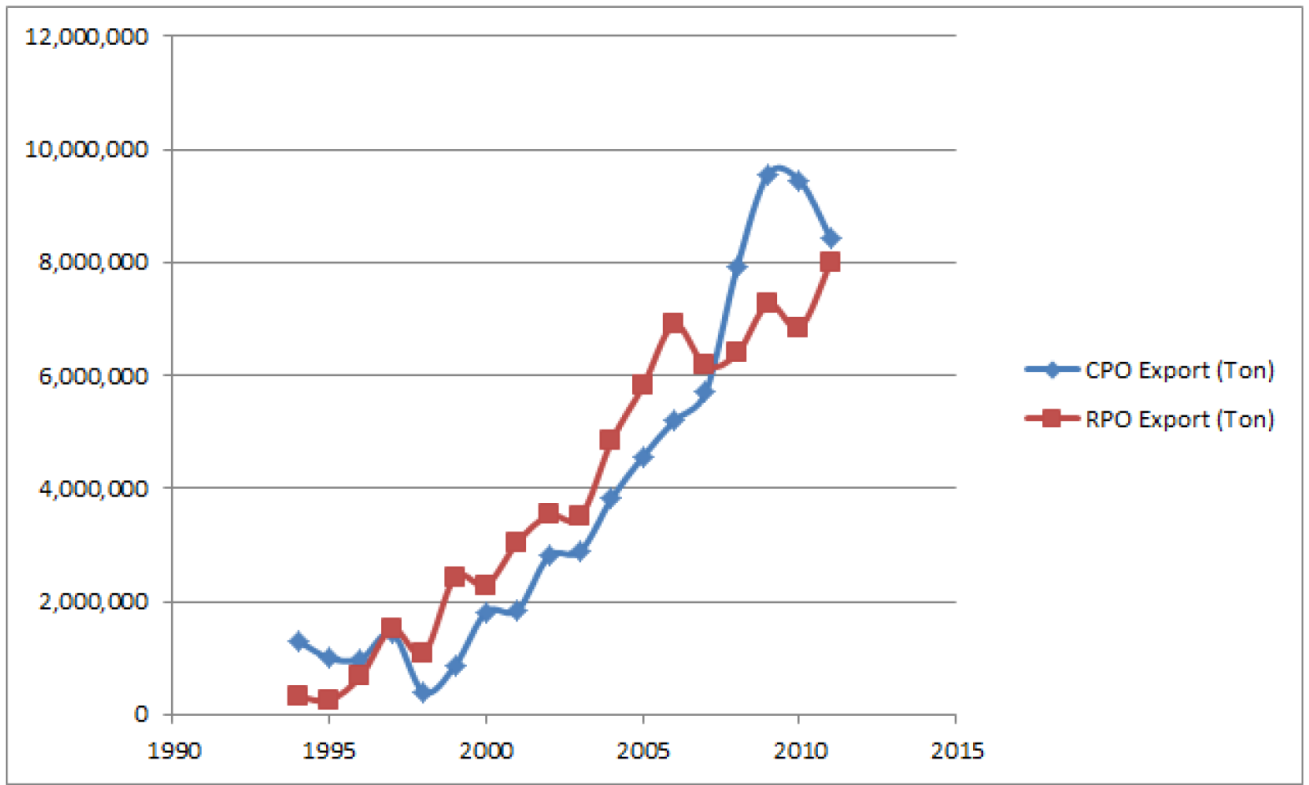

Data Source: UN Comtrade Database

Figure 8. Export of CPO and RPO of Indonesia (UN Comtrade Database, 2014) 
Figure 8 shows Indonesian CPO and RPO exports from 1994-2011. If government's export tax rate during 1994-2011 is compared side-by-side with CPO and RPO exports at that time, it can be observed that export taxes really do affect export level. Furthermore, it can be seen that during 2000 - 2006, where CPO export tax had been set at a higher rate than RPO export tax, there had been an increase in RPO exports. This is important, as exported RPO will obtain higher price (and means higher revenue) and at the end will contribute to a higher level of competitiveness eventually. This is made clear when we look at the government's export tax policies during 2005-2011. During 2005-2011, government altered CPO and RPO export taxes, where in 2007 and 2008 RPO export taxes had a higher rate than CPO export tax. This in turn caused a sudden increase in CPO export. In 2009 CPO and RPO export tax rates are roughly on the same level, but CPO exports were still significantly higher. It can be concluded that for the developed model, it is necessary to ensure that CPO export tax should always be higher than RPO export tax so that the downstream industry that follows will increase the competitiveness level for the industries.

\subsubsection{Fertilizer Subsidies and Replanting Policies}

Government tries to provide fertilizers for farmers (SH) at an affordable price by giving subsidies. The main goal of subsidies is to ensure that fertilizers have a reasonable and affordable price among farmers to maintain or even increase productivities. The amount of subsidies is affected by US Dollar exchange rate, because several raw materials are calculated on USD such as gas supply and other raw material. Figure 9 below shows how big fertilizer subsidy budget allocated by government year-to-year.

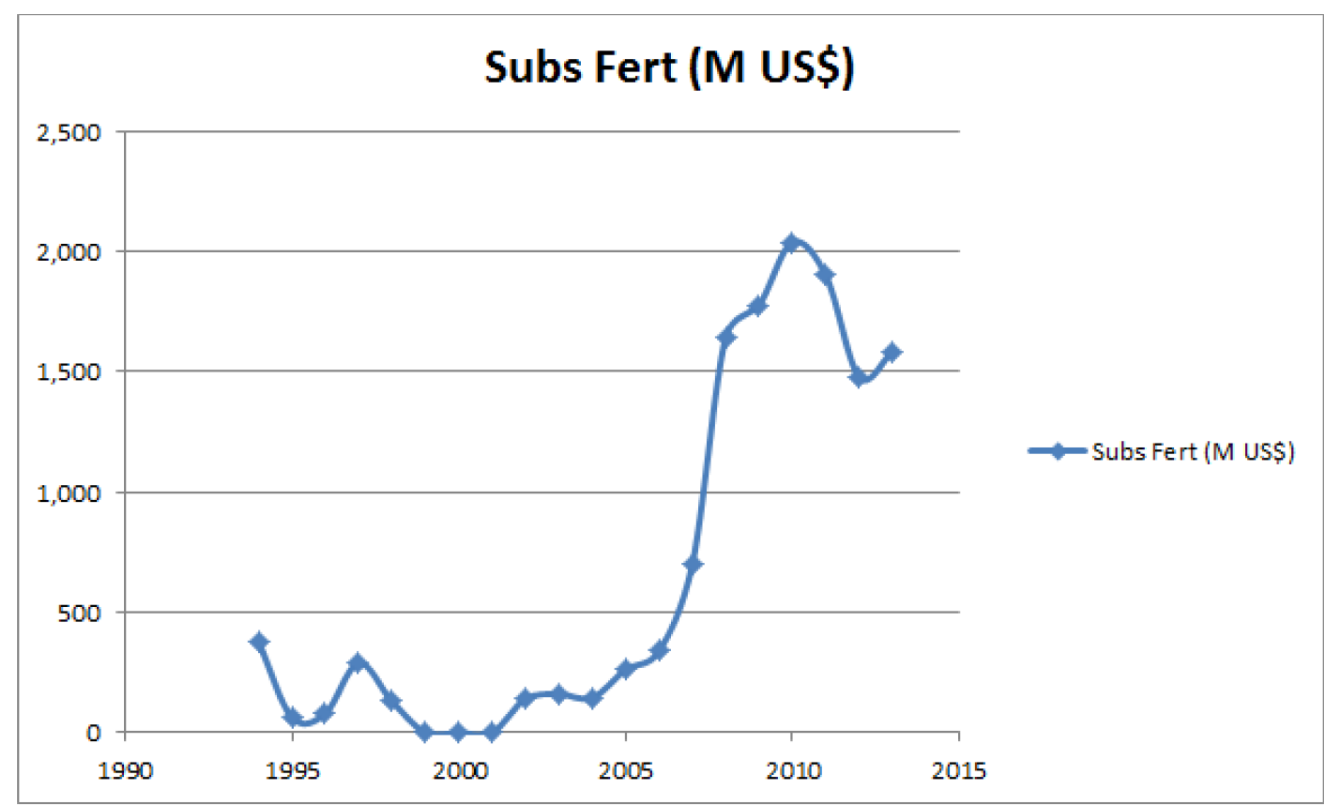

Figure 9. Fertilizer Subsidies during 1990-2010 
Subsidy policies are given to encourage increase in production, especially CPO production. The result of fertilization are not just an increase in Fresh Fruit Bunch (FFB) tonnage, which are the result of farming cultivation, but also increase in fruit yields, which can only be obtained after CPO production at processing plant.

Replanting subsidy policy is done to help independent farmers in increasing productivities. This has actually been asked by independent farmers association after suffering the impact from the rise of export tax. It has been suggested that some of the export tax acquired by government should have been returned to the farmers in the form of farm replanting subsidy. The rate of this replanting cost is around US\$735/hectare/year.

\subsubsection{ISPO Certification Policies}

Government establishes Indonesia Sustainable Palm Oil (ISPO) through the Permentan No $19 / 2011$, which is the decree of Ministry of Agriculture, about Indonesian Sustainable Palm Plantation. In accordance to the aforementioned rule, the application of ISPO is set to be as late as December $31^{\text {st }}, 2014$, but then it was delayed. With this policies, it was expected that palm production process will go hand-in-hand with environmental conservation, employee's well-being, and social activities inside the company, and also the implementation of a long-time best practice.

In general, the rules in ISPO are similar to that in Roundtable Sustainable Palm Oil (RSPO) which has been around since 2005. The main difference is that since ISPO is a government regulation established by Ministry of Agriculture, it is compulsory. If CPO export requires an ISPO certificate, then it is certain that upstream plantation industry will pay more attention to environmental issues and best practices. Several CPO exporters had received their ISPO certificates, which means that should the regulation is made compulsory, those exporters will meet the regulation.

\subsection{Model Formulation}

In formulating the model, the policy mix applied on models are described on Table 2 below.

\begin{tabular}{|c|c|c|}
\hline No & Policy & Affected subprocesses \\
\hline 1 & Fertilizer subsidies & CPO production \\
\hline 2 & CPO Export tax & CPO and RPO exports \\
\hline 3 & RPO export tax & RPO exports \\
\hline 4 & $\begin{array}{c}\text { Plantation area replanting subsidies } \\
\text { (with selected seedlings) }\end{array}$ & CPO productions \\
\hline 5 & $\begin{array}{c}\text { Mandatory ISPO Certification } \\
\text { for CPO exports }\end{array}$ & \\
\hline
\end{tabular}

Table 2. Policy Mix 
While the notation used in the model are explained below.

Index:

i: subprocess index $i=1$ to 6 where:

$\mathrm{i}=1$ is $\mathrm{CPO}$ production; $\mathrm{i}=2$ is $\mathrm{CPO}$ export; $\mathrm{i}=3$ is domestic CPO; $\mathrm{i}=4$ is RPO production; $\mathrm{i}=5$ is RPO export; $i=6$ is domestic RPO

t: stage/period (time)

$j$ : processes actors with $j=1$ is $S H ; j=2$ is $P C ; j=3$ is SC

Parameter:

$\beta \quad$ yield of RPO production from CPO

$c^{x} \quad$ Proportion of tax to be used for subsidy

$c^{b} \quad$ max CPO export tax allowed (\%)

$C^{c} \quad$ max RPO export tax allowed (\%)

$c^{R} \quad$ Cost of replanting (US\$/Ha)

$\gamma_{t}^{e} \quad$ Volume of ISPO Certified CPO (Ton)

Variable:

G competitiveness index

$G_{t} \quad$ competitiveness index at period $\mathrm{t}$

$\omega_{i t}^{I} \quad$ price of output $\mathrm{i}$ at period $\mathrm{t}$ (US\$/Ton) for Indonesia

$\omega_{i t}^{M} \quad$ price of output $\mathrm{i}$ at period $\mathrm{t}$ (US\$/Ton) for Malaysia

$Y_{i t}^{I} \quad$ total output of subprocess $\mathrm{i}$ at period $\mathrm{t}$ (Ton) for Indonesia

$Y_{i t}^{M} \quad$ total output of subprocess $\mathrm{i}$ at period $\mathrm{t}$ (Ton) for Malaysia

$S_{t}^{l} \quad$ value of market share of Indonesia at period $t$ (US\$)

$S_{t}^{M} \quad$ value of market share of Malaysia at period t (US\$)

$S_{t}^{W} \quad$ total world export for CPO and RPO at period $\mathrm{t}$ (US\$)

$a_{j t} \quad$ CPO productivity of actor $\mathrm{j}$ land at period $\mathrm{t}$ (Ton/Ha)

$X_{t} \quad$ tax collected at period $t$ (US\$)

$y_{j t} \quad$ output of subprocess CPO production by actor $\mathrm{j}$ at period $\mathrm{t}$ (Ton)

$m_{j t} \quad$ land area of actor $\mathrm{j}$ at period $\mathrm{t}(\mathrm{Ha})$

$m_{j t}^{o} \quad$ old oil palm farm area of actor $\mathrm{j}$ which need replanting at period $\mathrm{t}(\mathrm{Ha})$

$m_{j t}^{P} \quad$ productive area of actor $\mathrm{j}$ at period $\mathrm{t}(\mathrm{Ha})$

$\gamma_{t}^{a} \quad$ subsidy for fertilizer at period $\mathrm{t}$ (US \$)

$\gamma_{t}^{b} \quad$ RPO export tax at period $\mathrm{t}(\%)$

$\gamma_{t}^{c} \quad$ RPO export tax at period $\mathrm{t}(\%)$

$\gamma_{t}^{d} \quad$ subsidy for Replanting at period $\mathrm{t}$ (US\$) 
This model intends to maximize competitiveness index in form of market share as follows.

$$
\operatorname{Max} G=\sum_{t=1}^{n} G_{t}
$$

Where:

$$
G_{t}=\frac{S_{t}^{I}}{S_{t}^{W}}
$$

Indonesian market share is the sum of CPO export, RPO export, and domestic sales of RPO. The amount of each ton of RPO domestic sales is assumed to have higher values than RPO expot values per ton because it will produce a final product with higher added value. Using the closest final product of RPO, which is bulk cooking oil, the domestic RPO will have $10 \%$ higher price, and hence the domestic RPO sales per ton is determined as 1.1 times the export RPO price

$$
S_{t}^{I}=\sum_{i=1}^{6} \omega_{i t}^{I} Y_{i t}^{I}
$$

The aforementioned equation can also be used to determine sales from Malaysia:

$$
S_{t}^{M}=\sum_{i=1}^{6} \omega_{i t}^{M} Y_{i t}^{M}
$$

Total world sales is assumed to be a sum of sales from both countries:

$$
S_{t}^{W}=S_{t}^{I}+S_{t}^{M}
$$

Subject to:

A. CPO Production:

National CPO production of Indonesia is a sum of production from $\mathrm{SH}, \mathrm{PC}$, and SC:

$$
Y_{1 t}^{l}=y_{1 t}+y_{2 t}+y_{3 t}
$$

CPO production as a result from cultivation by PC and SC are multiplication of farming areas and productivity (ton $\mathrm{CPO} /$ hectare):

$$
\begin{aligned}
& y_{2 t}=m_{2 t} \alpha_{2 t} \\
& y_{3 t}=m_{3 t} \alpha_{3 t}
\end{aligned}
$$

The parameter $a$ is a productivity parameter. Here it is assumed that the productivity of the two actors are not affected by the government policy. CPO production from SH cannot use the same equation as the two aforementioned equations. $\mathrm{SH}$ production acquires fertilizer subsidies from government, of which the effect cannot be neglected. Using production data and fertilizer subsidies, a multiple regression equation can be formulated as follows:

$$
\text { CPO production of } S H=2.0634 m_{1 t}+862.035 \gamma_{t}^{a}-484879.815
$$


Smallholder CPO production is also affected by old and nonproductive plant replanting subsidy policy. There is cost for replanting including seedlings. Only after three years does these new plants can start to yield, so the additional production is acquired after 3 years:

$$
\text { Additonal production of year } t=\left(\gamma_{t-3}^{e} / c^{R}\right) \times \alpha_{1 t}
$$

Therefore the $\mathrm{CPO}$ production from $\mathrm{SH}$ is retrieved by incorporating equation 10 and 9 into:

$$
y_{1 t}=2.0634 m_{1 t}+862.035 \gamma_{t}^{a}-484879.815+\left(\gamma_{t-3}^{e} / c^{R}\right) \times \alpha_{1 t}
$$

\section{B. CPO Export and Domestic CPO}

CPO exports are affected by CPO production, export taxes, and export price. Using CPO production data, CPO export taxes, and export prices during 1994-2010, the equation is formulated as follows:

$$
\text { CPO Export }=0,38 \times Y_{2 t}^{I}-243556.4 \times \gamma_{t}^{b}+98.56 \times \omega_{2 t}^{I}+244856 \times \gamma_{t}^{c}-311414
$$

The volume of CPO export are limited by ISPO certification policy. Therefore CPO export is as much as Equation 11 if below the predicted certified quantity and equals the predicted certified quantity if the multiplication of Equation 11 exceeds it.

$$
\begin{gathered}
\text { If } \gamma e_{t} \geq 0.38 Y_{2 t}^{I}-243556.4 \gamma_{t}^{b}+98.56 \omega_{2 t}^{I}+244856 \gamma_{t}^{c}-311414 \\
\text { then } Y_{2 t}^{I}=0.381 Y_{1 t}^{I}-243556.4 \gamma_{t}^{b}+98.56 \omega_{2 t}^{I}+244856 \gamma_{t}^{c}-311414 \\
\text { Else } Y_{2 t}^{I}=\gamma_{t}^{e}
\end{gathered}
$$

Therefore, domestic CPO consumption is a difference between production and export:

$$
Y_{3 t}^{I}=Y_{1 t}^{I}-Y_{2 t}^{I}
$$

\section{RPO Production and Export}

RPO production is a function from domestic CPO multiplied by RPO production yield:

$$
Y_{4 t}^{I}=\beta Y_{3 t}^{I}
$$

RPO export is a function from domestic CPO, RPO export taxes, CPO export taxes, and RPO export price. A multiple regression equation is formulated as follows:

$$
Y_{5 t}^{I}=0.75 Y_{3 t}^{I}-72803.59 \gamma_{t}^{c}-1458.58 \omega_{5 t}^{I}+42881.05 \gamma_{t}^{b}-1204910.28
$$

Therefore RPO domestic consumption is determined from difference between production and export:

$$
Y_{6 t}^{I}=Y_{4 t}^{I}-Y_{5 t}^{I}
$$


D. Export Tax Limitation

CPO export taxes is set to be the same or higher than RPO export tax with limitations as follows:

$$
\begin{gathered}
\gamma_{t}^{c} \leq \gamma_{t}^{b} \\
0 \leq \gamma_{t}^{b} \leq c^{b} \\
0 \leq \gamma_{t}^{c} \leq c^{c}
\end{gathered}
$$

\section{E. Subsidy Limitation}

The amount of subsidies cannot exceed a proportion of the amount of predicted income from received export tax:

$$
\gamma_{t}^{a}+\gamma_{t}^{d} \leq c^{X} X_{t}
$$

Where the amount of tax income is retrieved from:

$$
X_{t}=\gamma_{t}^{b} Y_{2 t}^{I} \omega_{2 t}^{I}+\gamma_{t}^{c} Y_{5 t}^{I} \omega_{5 t}^{I}
$$

F. Land Limitation:

The equation limits the amount of subsidy budget for replanting which should be less than overall cost for non-productive areas:

$$
\gamma_{t}^{e} / c^{R} \leq m_{1 t}^{O}
$$




\section{Result and Discussion}

The model is applied to simulate year 2014-2018, using COMTRADE and Indonesian Central Agency of Statistics data. Model optimization is done using Lingo v11.0 software. The output quantity from every subprocess as a result of optimum solution is presented on Table 3 below. The policies and competitiveness index of Indonesia and Malaysia are presented on Table 4.

\begin{tabular}{|c|r|r|r|r|}
\hline \multirow{2}{*}{ Pred Year } & $\begin{array}{c}\text { SH } \\
\text { y1t (Ton) }\end{array}$ & $\begin{array}{c}\text { PC } \\
\text { y2t (Ton) }\end{array}$ & $\begin{array}{c}\text { SC } \\
\text { y3t (Ton) }\end{array}$ & \multicolumn{2}{c|}{$\begin{array}{c}\text { CPO Total } \\
\text { Y2t }\end{array}$} \\
\hline 2014 & $9,926,466$ & $15,794,220$ & $2,388,399$ & $28,109,085$ \\
\hline 2015 & $10,344,220$ & $16,880,890$ & $2,439,969$ & $29,665,079$ \\
\hline 2016 & $10,761,970$ & $18,002,220$ & $2,491,539$ & $31,255,729$ \\
\hline 2017 & $11,376,860$ & $19,158,210$ & $2,543,109$ & $33,078,179$ \\
\hline 2013 & $11,807,260$ & $20,348,870$ & $2,594,679$ & $34,750,809$ \\
\hline
\end{tabular}

\begin{tabular}{|c|r|r|r|r|r|}
\hline Pred Year & $\begin{array}{c}\text { Y3t } \\
\text { Exp CPO (Ton) }\end{array}$ & Y4t (Ton) & Y5t & $\begin{array}{c}\text { Y6t } \\
\text { Exp RPO (Ton) }\end{array}$ & $\begin{array}{c}\text { Y7t } \\
\text { Dorn RPO (Ton) }\end{array}$ \\
\hline 2014 & $4,900,000$ & $23,209,090$ & $21,816,540$ & $14,982,300$ & $6,834,245$ \\
\hline 2015 & $5,600,000$ & $24,065,070$ & $22,621,170$ & $15,585,100$ & $7,036,066$ \\
\hline 2016 & $6,300,000$ & $24,955,720$ & $23,458,380$ & $16,213,910$ & $7,244,466$ \\
\hline 2017 & $7,000,000$ & $26,078,180$ & $24,513,490$ & $17,016,730$ & $7,496,761$ \\
\hline 2018 & $7,700,000$ & $27,050,810$ & $25,427,760$ & $17,707,090$ & $7,720,674$ \\
\hline
\end{tabular}

Table 3. Model Output: Subprocesses

\begin{tabular}{|c|r|r|r|}
\hline Pred Year & $\begin{array}{c}\text { Subsidy } \\
\text { (M US\$) }\end{array}$ & $\begin{array}{c}\text { Exp Tax CPO } \\
\text { Ybt (\%) }\end{array}$ & \multicolumn{2}{|c|}{$\begin{array}{c}\text { Exp Tax RPO } \\
\text { Yet (\%) }\end{array}$} \\
\hline 2014 & $1,889.87$ & 19.00 & 19.00 \\
\hline 2015 & $1,889.87$ & 19.00 & 19.00 \\
\hline 2015 & $1,889.87$ & 19.00 & 19.00 \\
\hline 2017 & $1,889.87$ & 19.00 & 19.00 \\
\hline 2013 & $1,839.87$ & 19.00 & 19.00 \\
\hline
\end{tabular}

\begin{tabular}{|c|r|r|r|r|}
\hline Pred Year & $\begin{array}{c}\text { Sub Per 1 dan } \\
\text { ydt (US\$) }\end{array}$ & $\begin{array}{c}\text { ISPO } \\
\text { yht (Ton) }\end{array}$ & \multicolumn{1}{|c|}{ IDS } & IDS M \\
\hline 2014 & $161,963,900$ & $4,900,000$ & 0.574 & 0.426 \\
\hline 2015 & $163,830,200$ & $5,600,000$ & 0.530 & 0.420 \\
\hline 2016 & 0 & $6,300,000$ & 0.585 & 0.415 \\
\hline 2017 & 0 & $7,000,000$ & 0.591 & 0.409 \\
\hline 2013 & 0 & $7,700,000$ & 0.595 & 0.404 \\
\hline
\end{tabular}

Table 4. Model Output: Policies and Competitiveness 


\subsection{CPO Production}

Indonesian CPO production yields are presented on Table 3. CPO production is a sum of CPO production from SH, SC, and PC. Figure 10 shows production quantity from each actors. It can be seen that production is increasing, and production proportion from $\mathrm{SH}$ is growing, because of fertilizer subsidies.

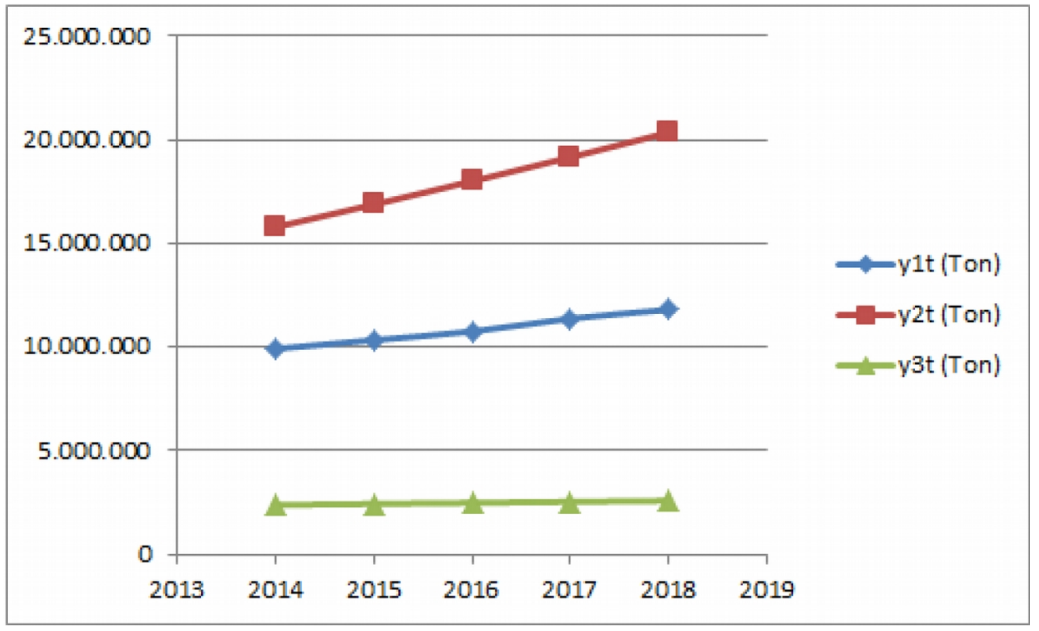

Figure 10. Proportion of $\mathrm{SH}(\mathrm{y} 1 \mathrm{t}), \mathrm{PC}(\mathrm{y} 2 \mathrm{t})$, and $\mathrm{SC}(\mathrm{y} 3 \mathrm{t})$ on CPO production

Other than fertilizer subsidies, CPO production is also a subject to replanting program. Unlike fertilizer subsidy, the effect of replanting will only start to show its results after three years. This is partly due to a recently planted palm tree will only start to yield after three years. For instance, a replanting in 2012 will only start to yield in 2015. RPO production from modelling is presented in Table 3. There is a significant step-up of RPO production because of CPO export-limiting ISPO certification limitations.

Government policies related to the productivity improvement actualy are the government support for technology capability. It can be seen that if equation 11 is changed in the form of equation 7 or 8 then the improvent in productivity $(a)$ because of technology enhancement can be revealed. Here the model only accomodates subsidy and replanting policies, but the same characteristic policies can also be given to the next subprocess like RPO production. 


\subsection{CPO and RPO Exports}

Table 3 above has shown the amount of CPO and RPO exports during 2014-2018 based on the developed model. Graphical representation is presented in Figure 11 below.

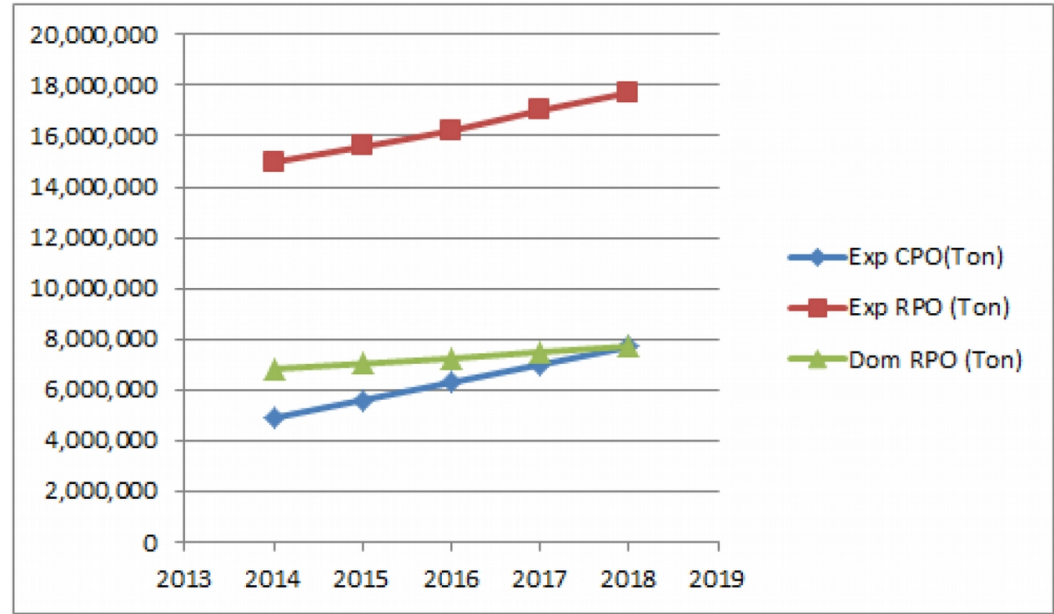

Figure 11. Model Solution: CPO Export, RPO export and domestic RPO

It can be seen that this results show improvement in the performance of Indonesian CPO and RPO exports, compared to the exports in 2004-2011 which shown by Figure 8 earlier. Performance improvements are not just in total quantity, but also in a larger RPO export proportion. As a comparison, Malaysia did the same thing during 2005-2011 as presented by Figure 3. It can be observed that there is a huge difference between RPO and CPO exports. Malaysian RPO exports are higher than CPO exports, because of high tax for CPO and an export quota for CPO. This strategy ensures that for every ton CPO yielded will result in a higher export value after processed into downstream product which will obtain a higher price. With the developed models, Indonesia also ensures a higher level of downstream products, so that even though Malaysia increased the production quantity of their downstream product to the highest level, it will never be able to compete with Indonesia.

Policies that affects CPO and RPO exports are CPO and RPO export taxes. Results from the model shows that optimum solution is obtained from establishing CPO and RPO export taxes on high limit, which is $19 \%$ respectively. This result is acceptable, considering that models will try to achieve a maximum possible budget to fund the increase in CPO production in forms of fertilizer subsidies, land replanting, and if necessary, an increase in RPO processing capacity. It can be seen that by ensuring that CPO export tax is made higher than RPO export tax, this difference in export can be maintained in the future.

Equation 11 and 12 (CPO Export) shows that CPO export tax is in negative. This means that a rise in export tax will in turn reduce the level of CPO export. In Equation 16 (RPO export), RPO 
export tax is in negative. This means that a rise in RPO export tax level will reduce the export rate of RPO, while an increase in CPO export tax will increase RPO export rate.

\subsection{Competitiveness}

Table 4 shows the Competitiveness Index result of Indonesia and Malaysia, and graphical representation of them is presented in Figure 12. From the chart, it is clear that Indonesia's competitiveness holds on and steadily increases against Malaysia. This improves the competitiveness steadily. This can be compared with condition before implementation of the model during 2005-2011 as shown in Figure 13.

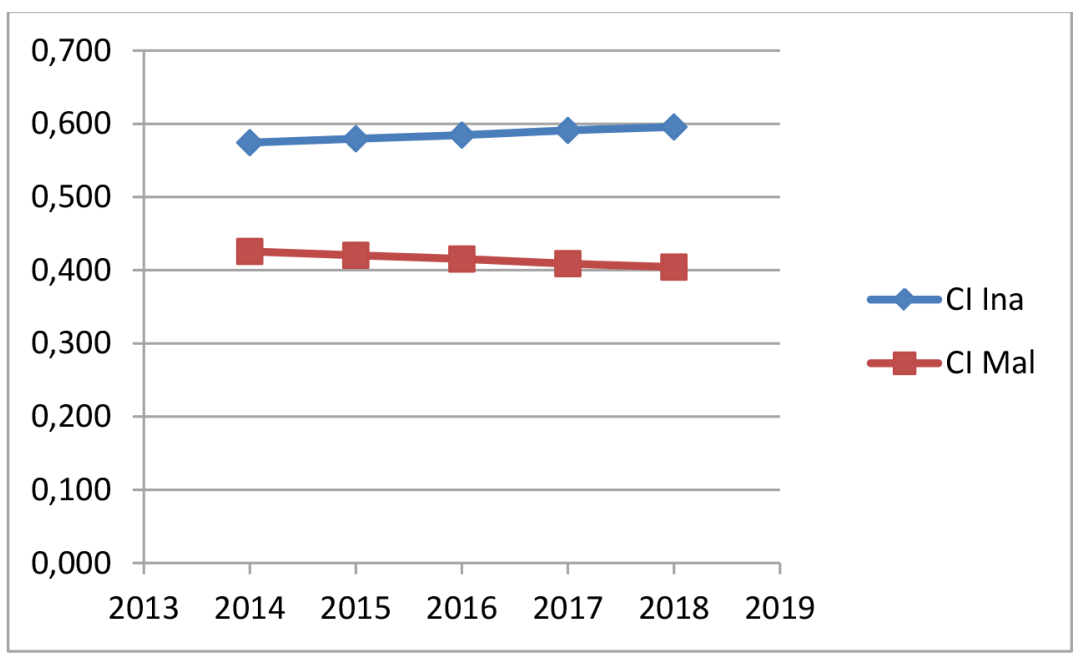

Figure 12. Model Output: Competitiveness Index of Indonesia and

$$
\text { Malaysia }
$$

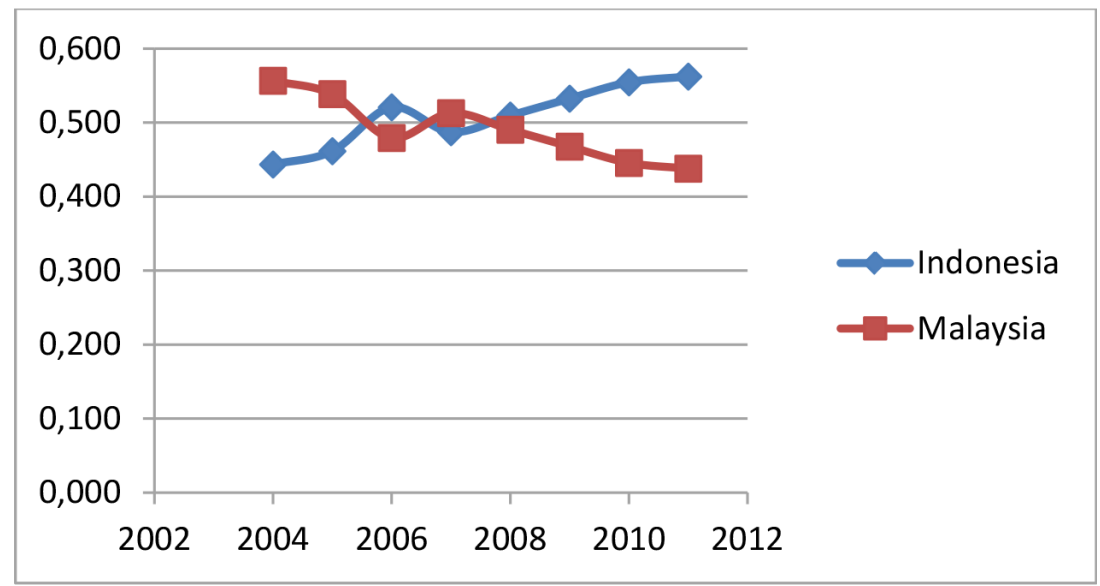

Figure 13. Competitiveness Index of Indonesia and Malaysia during 2004-2011 
Competitiveness index level is affected by higher RPO export proportion compared with CPO export. Moreover, domestic RPO consumption also plays an important role in shaping the competitiveness. Internal consumption of RPO commodities will certainly be processed even further to products with higher level of competitiveness. In this model, RPO price per ton consumed locally is assumed $10 \%$ higher than that of the exported RPO, because these domestic RPO products will gain a higher added value. Looking back to Figure 11, it shows the quantity of RPO consumed locally. It can be seen that local RPO consumption is higher than the CPO exports. This shows that local RPO consumption plays a more significant contribution in competitiveness index than the CPO exports.

\section{Conclusion and Further Study}

The study presents the model of Indonesian Palm oil industry competitiveness, by considering the government policy as the coordinator. The main goal of this model is to accommodate government's policy mix to be applied on the model which is then optimized. The model has been built structurally based on hierarchical multi-level system approach, while in the process element, the subprocesses are built using VCA approach. The conceptual model represented the relations between the processes, government and macro economic environment. The model can simulate industry performance, and show that such government policy mix can improve the competitiveness of Indonesian palm Oil Industry. The model has a potential to be applied to other agri-industry, especially an industry which has long chains, with several downstream products.

The model built has also implemented a downstreaming strategy which is thought to be the correct strategy in ensuring sustainable competitiveness. Based on the model, it is understood that local and export proportion needs to be neatly adjusted in order to increase the competitiveness.

The model developed is more an economic model but it has a potential to show the techno-economic aspect. It has been shown that there are policies which influence the technology capability. If the model is further developed to put supporting subprocess like research and development, the policy to support this subprocess can be described, and the result can be monitored at production subprocesses.

The model can also be further developed to accommodate many policy mix. The applied policies basically have two purposes, to increase production in a subprocess and to regulate the proportion whether to be exported or to be continued to the next subprocess locally. In this way, this model can be developed using variations of these two kind of policies. The model can also be developed to accommodate many possible scenarios, in relation with macro economic situations, government policy mix to cope those situations, and change in strategy done by competitors. 


\section{References}

Akyuwen, R., \& Sulistyanto, A.I. (2010). The Dynamics of Crude Palm Oil Export. AFBE 2010 Conference Papers. ISSN 1905-8055, 1-40.

Badan Pusat Statistik (Indonesian Central Agency of Statistics) (2012). Statistik Kelapa Sawit Indonesia 2011. Katalog BPS, 5504003.

Chalil, D. (2008). An Empirical Analysis of Asymmetric Duopoly in the Indonesian Crude Palm Oil Industry. Doctoral Thesis, Faculty of Agricultural, Food and Natural Resource. University of Sidney, New South Wales, Australia.

Hasan, M.F., Reed, M.R., \& Marchant, M.A. (2001). Effect of an Export Tax on Competitiveness: The Case of the Indonesian Palm Oil Industry. Journal of Economic Development, 26(2), 77-90.

Kaplinsky, R., \& Morris, M. (2001). A Handbook for Value Chain Research. IDRC.

Lall, S. (2004). Reinventing Industrial Strategy: The Role of Government Policy in Building Industrial Competitiveness. United Nations Conference on Trade and Development, 28.

Marks, S.V., Larson, D.F., \& Pomeroy, J. (1998). Economic Effects of Taxes on Exports of Palm Oil Products. Bulletin of Indonesian Economic Studies, 34(3), 37-58. http://dx.doi.org/10.1080/00074919812331337410

Martin, L., Westgren, R., \& van Duren, E. (1991). Agribusiness Competitiveness Across National Boundaries. AAEA report. http://dx.doi.org/10.2307/1242402

Mesarovic, M.D., Macko, D., \& Takahara, Y. (1970). Theory of Hierarchical, Multilevel Systems. Academic Press, New York \& London

Porter, M.E. (1990). The Competitive Advantage of Nations. New York, NY: Free Press. http://dx.doi.org/10.1007/978-1-349-11336-1

Rifin, A. (2009). Export Competitiveness of Indonesia's Palm Oil Product. Trends in Agricultural Economics, Asean Network for Scientific Information.

Rifin, A. (2010). The Effect of Export Tax on Indonesia's Crude Palm Oil (CPO) Export Competitiveness. Asean Economic Buletin, 27(2), 173-184. http://dx.doi.org/10.1355/ae27-2b

Siggel, E. (2006). International Competitiveness and Comparative Advantage: A Survey and a Proposal for Measurement. J Ind Compet Trade, 6, 137-159. http://dx.doi.org/10.1007/s10842-006$8430-x$

Siggel, E., \& Ssemogerere, G. (2004). Uganda's Policy Reforms, Industry Competitiveness and Regional Integration: A Comparison with Kenya. J. Int. Trade \& Economic Development, 13(3), 325-357. http://dx.doi.org/10.1080/0963819042000240057 
Silitonga, R.Y.H., Nur-Bahagia, S., Simatupang, T., \& Siswanto, J. (2013). Modeling the Competitiveness of Indonesian Palm Oil Industry. Proceeding International Conference "Logistic and Supply Chain Management". Bali, Indonesia. 193-198.

Susila, W.R. (2004). Impacts of CPO Export Tax on Several Aspects of Indonesian CPO Industry. Oil Palm Industry Economic Journal, 4(2).

Tambunan, T. (2006). Indonesian Crude Palm Oil: Production, Export Performance and Competitiveness. Working Paper Series no. 8. Center for Industries and SME Studies, Faculty of Economics, University of Trisakti.

UN Comtrade Database, United Nations, (2014). Available online at: http://comtrade.un.org/data/

Journal of Industrial Engineering and Management, 2016 (www.jiem.org)

Article's contents are provided on an Attribution-Non Commercial 3.0 Creative commons license. Readers are allowed to copy, distribute and communicate article's contents, provided the author's and Journal of Industrial Engineering and Management's names are included. It must not be used for commercial purposes. To see the complete license contents, please visit http://creativecommons.org/licenses/by-nc/3.0/. 